\title{
WATER QUALITY DEgRADATION AFTER WATER STORAgE AT HOUSEHOLd LEVEL IN A PIPED WATER SYSTEM IN RURAL GUATEMALA
}

\author{
Steven E. Lacey, PhD, CIH, CSP \\ University of Illinois at Chicago \\ Division of Environmental and Occupational Health Sciences \\ Chicago, IL 60612 \\ slacey@uic.edu \\ Ramon Lopez, MS \\ University of Illinois at Chicago \\ Division of Environmental and Occupational Health Sciences \\ Chicago, IL 60612 \\ rlopez1ster@gmail.com \\ Charles Frangos, EI \\ Clark Dietz, Inc. \\ Chicago, IL USA \\ charles.frangos@clarkdietz.com \\ Amid Khodadoust, PhD \\ University of Illinois at Chicago \\ Department of Civil \& Materials Engineering \\ Chicago, IL USA \\ akhodado@uic.edu
}

\begin{abstract}
In response to a rural community's concern regarding diarrheal disease, particularly among children, a field assessment was performed to determine the concentration of 4 classes of indicator bacteria: aerobic bacteria, total coliform, fecal coliform and Escherichia coli. Matched supply tap and storage container samples were taken from 28 households; two additional samples were taken at the main storage tank. Total and free chlorine concentration was also determined for each sample. While nearly all samples taken from household taps were near or below limits of detection, samples from storage containers all showed high densities of indicator bacteria and one was positive for Salmonella. All chlorine measurements indicated concentrations of $<0.5 \mathrm{ppm}$. These data suggest that while the source well water shows indicator bacteria concentrations at or below limits of detection, drinking water becomes significantly more hazardous while in storage containers at the household level, and this reflects insufficient chlorination. An uninterrupted and adequately chlorinated water supply system is planned to eliminate the need for drinking water storage at the household level.
\end{abstract}


Index Terms - Guatemala, microbial contamination, water quality, water storage

\section{INTRODUCTION}

An initial community health assessment identified diarrheal disease, particularly among children, as a primary morbidity concern for a rural community in Guatemala. Informal discussions with several community leaders suggested that $60-90 \%$ of children and 3-40 \% of adults suffer at least one episode of gastroenteritis per year. Water is available to sectors of the community on a rotating basis, so drinking water must be stored at individual households for 2 to 3 days between re-supply. Several reports have indicated that microbiologically clean sources of drinking water become contaminated after water collection and subsequent storage at the household level and contaminated source water quality declines further with storage. $\mathrm{i}_{\text {, ii ii, iv, v, vi }}$

An assessment strategy utilizing matched water samples from the supply tap and storage container at the household level were collected to determine the concentration of 4 classes of indicator bacteria. These data will help inform an intervention strategy entailing an uninterrupted and adequately chlorinated water distribution system. Also, these data are useful to those concerned with safe drinking water in rural communities in developing countries to anticipate the type, concentration and possible sources of contamination. In addition, the methods used provide an assessment strategy to characterize contamination in similar rural settings. To our knowledge, no published data is available on the quality of well water and stored drinking water in Guatemala.

This work was performed by the Engineers Without Borders Student Chapter at the University of Illinois at Chicago. This multidisciplinary team is comprised of students and faculty mentors from nearly all disciplines of engineering, public health, and urban planning. The composition of this team facilitates learning across professions, and establishes the necessary framework to approach and the skills to solve complex public health problems.

\section{Study location}

Cerro Alto and Labor de Falla are small, neighboring rural communities in the mountainous region of Chimaltenango, Guatemala, approximately $30 \mathrm{~km}$ west of Guatemala City (Figure 1). The community is comprised of approximately 160 households (approximately 1,400 residents) of predominantly Kaqchikel Mayan decent, and covers $4.5 \mathrm{~km}^{2}$ at an elevation of 1,890 m. 


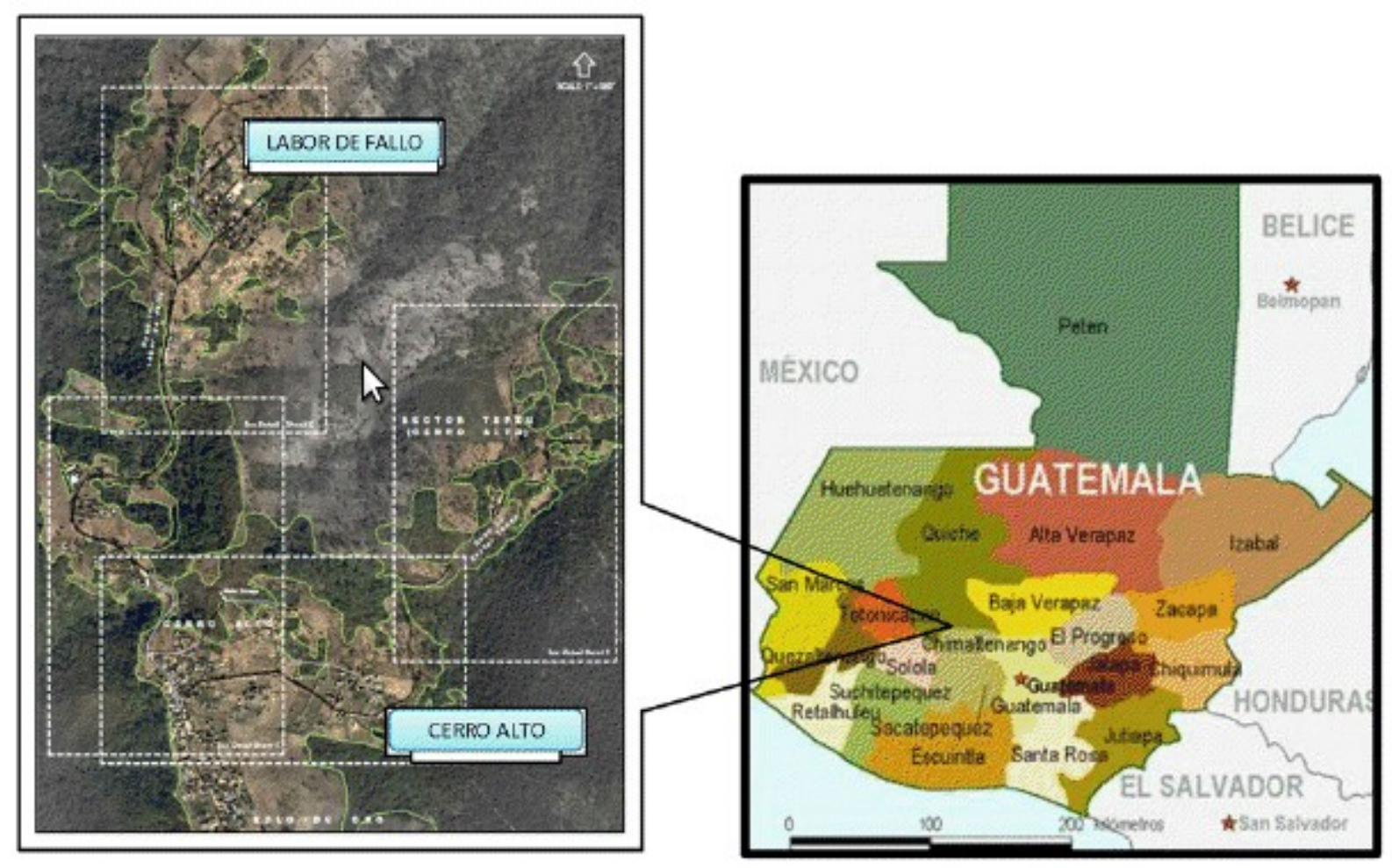

FIGURE 1

Project Location

\section{Water distribution system}

The system currently in place is six years old; prior to its installation, residents would have had to walk several kilometers to retrieve spring water. In the currently existing system (Figure 2), water is pumped from an approximately $245 \mathrm{~m}$ deep well to a main storage tank measuring $9 \times 4$ x $2 \mathrm{~m}$ (total volume of $72 \mathrm{~m}^{3}$ ) at a regional high point (elevation $1900 \mathrm{~m}$ ). When the storage tank is nearly full, a series of valves are manually opened and water is gravity fed through a polyvinyl chloride pipe distribution network to individual households; each household has a single water tap.

The distribution network is divided into three area sections with rotating service, such that each section is provided water for 4 to 5 hours once every 2 to 3 days, necessitating water storage for washing, bathing and drinking. Each household has a cement or a wooden frame with plastic liner cistern which is filled from the tap to hold water for washing and bathing (Figure 3). The cisterns are typically $3 \times 2 \times 1 \mathrm{~m}$ (total volume of approximately $6 \mathrm{~m}^{3}$ ) in size and are uncovered. Separate drinking water storage container(s) are filled from the tap; these are typically 20 or 40 L plastic containers and are usually covered. 


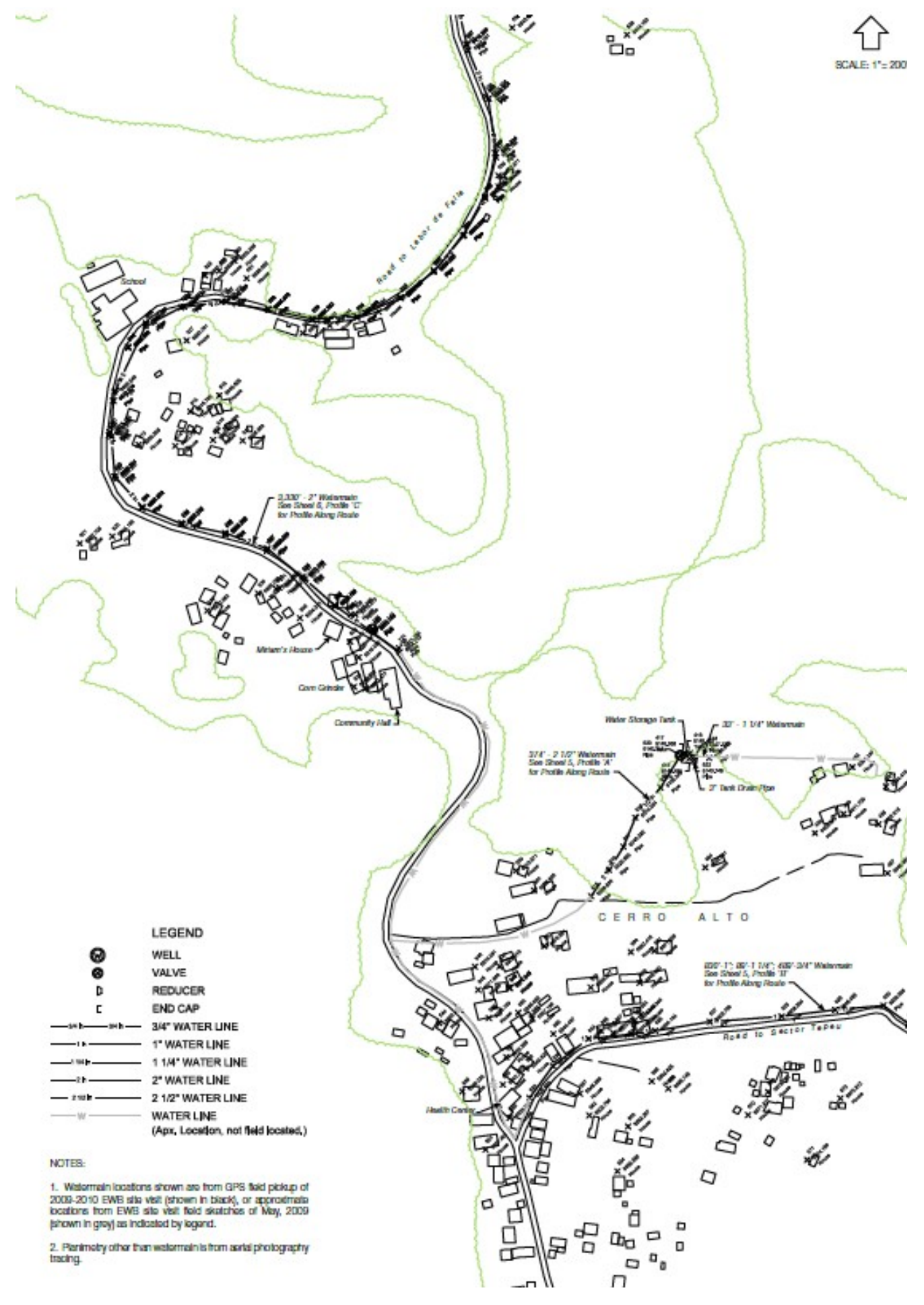

FIGURE 2

CURRENTLY EXISTING SYTEM 

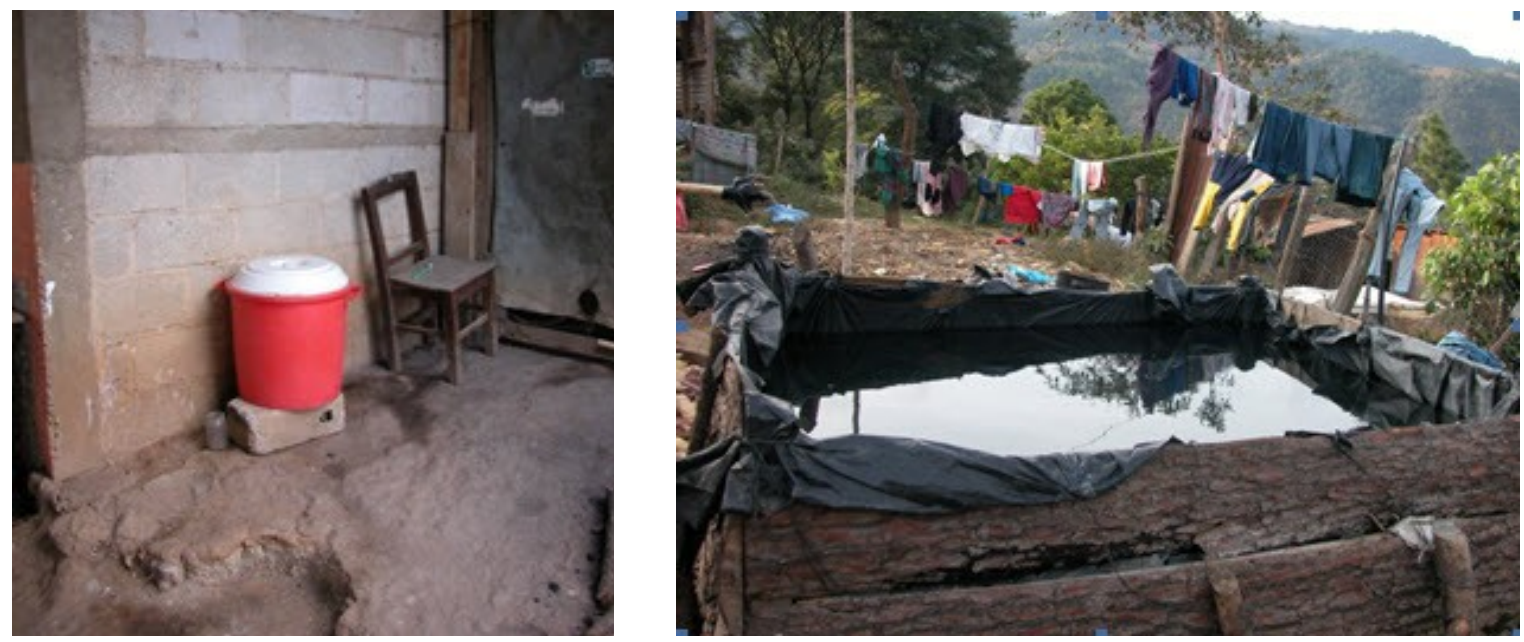

FIGURE 3

Typical Household Water Storage Containers

The local government had very recently installed a basic chlorination system where the supply line from the well enters the main cistern. A small volume from the supply line to the storage tank is diverted to a mixing cylinder that utilized 3-5 70\% calcium hypochlorite tablets, and then plumbed into the main storage tank. The local government provided instructions on how and when to use the chlorine to disinfect the drinking water, but provided only a few tablets for demonstration purposes. The community leadership wanted to spend as little money as possible for disinfection, and subsequently rationed the remaining chlorine using only a third of the minimum recommended dose.

\section{METHODS}

\section{Preliminary water testing}

Initial limited field sampling with LaMotte $\bigodot$ TC-5 Presence/Absence Coliform Bacteria Test kits (Chestertown, MD) determined presence of coliform bacteria in drinking water which prompted a systematic microbiological sampling campaign presented here.

\section{Microbiological sampling}

The water distribution system was mapped utilizing a handheld GPS device to identify the spatial location of all major features of the water distribution system and locations of homes in the community; these data were uploaded to ArcGIS and displayed over local topographical maps. Household sample sites were then randomly selected using satellite orthophotographs to attain representative spatial distribution that was reflective of the household density in a given area (Figure 4). To examine possible differences in bacterial contamination between water being supplied to the household supply tap versus drinking water in household storage containers, one sample from the household tap and one sample from the drinking water storage container were obtained from twenty-eight households (approximately 18\% of households in the community). 
The number of samples collected was limited by the field time available due to terrain and travel time to the laboratory, and budget limitations of our service organization. Since different areas of the village were supplied water only every 2-3 days, each home was visited twice during our two days of sampling: when water was being supplied to collect tap samples, and again to collect samples from the drinking water storage container on the non-delivery days. Samples were collected in $175 \mathrm{ml}$ sterile containers. Drinking water storage container samples were taken at the top of the water line from the center of the storage container, reflective of typical use by the community. For tap samples, water was either already flowing when we arrived at the household (during water delivery) or was permitted to flow approximately 15 seconds before collection. All sampling was conducted over two consecutive mornings. Collected samples were placed on ice in a cooler, and then transported to Guatemala City for analysis at a local commercial laboratory; the longest time between collection of the first sample and delivery to the laboratory was approximately 7 hours.

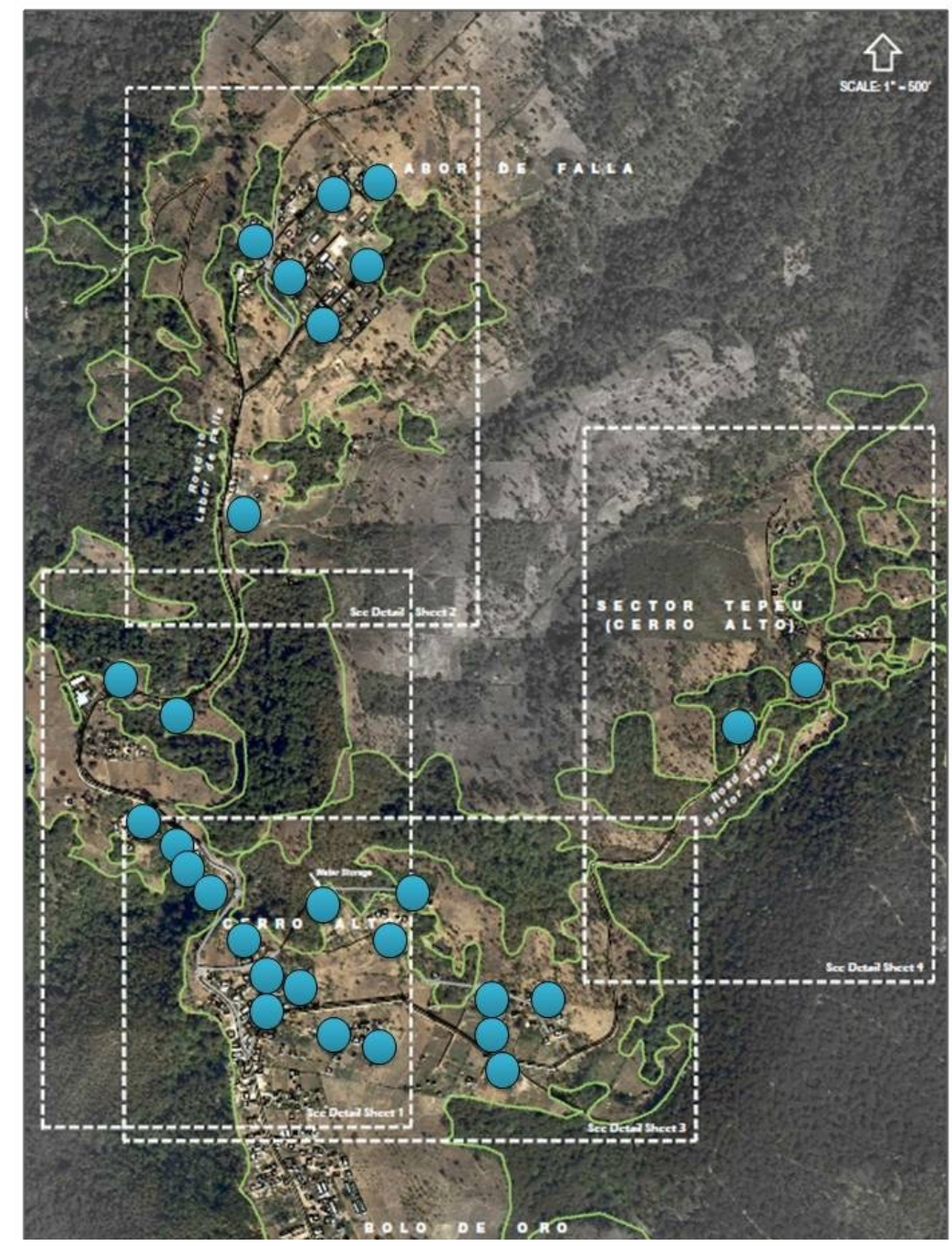

FIGURE 4

Microbiological and Chlorine Sampling Locations 
Wastewater (APHA/AWWA/WWF 1998) and included aerobic bacteria, total coliform, fecal coliform and Escherichia coli (E. coli) concentration and detection for presence of Salmonella. These 4 indicator bacteria were selected due to their significance for public health. Aerobic bacteria count was determined using the Heterotrophic Plate Count Method 9215. The limits of detection for aerobic bacteria were 10 to $57000 \mathrm{CFU} / \mathrm{ml}$. Total coliform count was determined using the Standard Total Coliform Fermentation Technique 9221B. The most probable number (MPN) of bacterium was determined to estimate the mean density of coliform in the sample. Fecal coliform count was determined using the Fecal Coliform Procedure 9221E. The MPN method was then used to estimate the mean density of coliform in the sample. E. coli count was determined using the Escherichia coli Procedure 9221F. The MPN method was then used to estimate the mean density of $E$. coli. The limits of detection for total coliform, fecal coliform and E. coli were 2 to $1600 \mathrm{MPN} / 100 \mathrm{ml}$. Samples were analyzed for Salmonella using a qualitative technique as described in Method 9260B.

\section{Chlorine sampling}

Total and free chlorine concentration was determined in the field for each supply tap and drinking water storage container at the households where sampling for indicator bacteria was performed. Hach Water Quality Test Strips (Loveland, CO) were utilized, with a detection range of 0 to $10 \mathrm{ppm}$, scaled at $0.5 \mathrm{ppm}$ increments.

\section{Data analysis}

Geometric means for aerobic bacteria, total coliform, fecal coliform and $E$. coli were determined. Lower and upper censored values in the dataset were addressed by using probability plotting to estimate the geometric means without including the censored values.

\section{RESULTS}

\section{Microbiological results}

Table I shows sample location, sample type (storage container or tap), aerobic bacteria concentration (CFU/ml), and total coliform, fecal coliform and E. coli counts (MPN/100ml), and Salmonella presence for each household sampled, along with 2 samples taken at the main storage tank. The aerobic bacteria concentration geometric mean for all tap samples was $17 \mathrm{CFU} / \mathrm{ml}$ and the geometric mean for all storage container samples was $28000 \mathrm{CFU} / \mathrm{ml}$. The average total coliform concentration for all tap samples was $5 \mathrm{MPN} / 100 \mathrm{ml}$ and the average for all storage container samples was $171 \mathrm{MPN} / 100 \mathrm{ml}$. The average fecal coliform concentration for all tap samples was $<2 \mathrm{MPN} / 100 \mathrm{ml}$ and the average for all storage container samples was 17 MPN/100ml. The average E. coli concentration for all tap samples was $<2 \mathrm{MPN} / 100 \mathrm{ml}$ and the average for all storage container samples was $6 \mathrm{MPN} / 100 \mathrm{ml}$. One sample, Household \#28, tested positive for salmonella. 
TABLE I

MICROBIOLOGICAL RESULTS BY HOUSEHOLD AND SAMPLE TYPE

\begin{tabular}{|c|c|c|c|c|c|c|}
\hline $\begin{array}{l}\text { Household / } \\
\text { Location }\end{array}$ & Sample Type & $\begin{array}{l}\text { Aerobic bacteria } \\
\text { (CFU/ml) }\end{array}$ & $\begin{array}{l}\text { Total Coliform } \\
\text { (MPN/100ml) }\end{array}$ & $\begin{array}{l}\text { Fecal Coliform } \\
\text { (MPN/100ml) }\end{array}$ & $\begin{array}{c}\text { E. coli } \\
\text { (MPN/100ml) }\end{array}$ & $\begin{array}{c}\text { Salmonella } \\
\text { Presence }\end{array}$ \\
\hline \multirow[t]{2}{*}{1} & Storage Container & 3500 & 48 & 17 & 17 & Negative \\
\hline & Tap & 10 & $<2$ & $<2$ & $<2$ & Negative \\
\hline \multirow[t]{2}{*}{2} & Storage Container & 22000 & 23 & 13 & 4 & Negative \\
\hline & Tap & 2200 & 1600 & 40 & 40 & Negative \\
\hline \multirow[t]{2}{*}{3} & Storage Container & $>57000$ & 140 & 23 & 8 & Negative \\
\hline & Tap & 15 & $<2$ & $<2$ & $<2$ & Negative \\
\hline \multirow[t]{2}{*}{4} & Storage Container & $>57000$ & $>1600$ & 7 & $<2$ & Negative \\
\hline & Tap & 10 & 2 & $<2$ & $<2$ & Negative \\
\hline \multirow[t]{2}{*}{5} & Storage Container & $>57000$ & 170 & 8 & $<2$ & Negative \\
\hline & Tap & 10 & $<2$ & $<2$ & $<2$ & Negative \\
\hline \multirow[t]{2}{*}{6} & Storage Container & $>57000$ & $>1600$ & 9 & 9 & Negative \\
\hline & Tap & $<10$ & $<2$ & $<2$ & $<2$ & Negative \\
\hline \multirow[t]{2}{*}{7} & Storage Container & 2600 & 30 & 23 & 2 & Negative \\
\hline & Tap & 30 & $<2$ & $<2$ & $<2$ & Negative \\
\hline \multirow[t]{2}{*}{8} & Storage Container & 6300 & 2 & $<2$ & $<2$ & Negative \\
\hline & Tap & $<10$ & $<2$ & $<2$ & $<2$ & Negative \\
\hline \multirow[t]{2}{*}{9} & Storage Container & 3200 & 350 & 13 & 2 & Negative \\
\hline & Tap & $<10$ & $<2$ & $<2$ & $<2$ & Negative \\
\hline \multirow[t]{2}{*}{10} & Storage Container & 3200 & 50 & 7 & $<2$ & Negative \\
\hline & Tap & 70 & $<2$ & $<2$ & $<2$ & Negative \\
\hline \multirow[t]{2}{*}{11} & Storage Container & 24000 & 240 & 22 & 9 & Negative \\
\hline & Tap & 20 & $<2$ & $<2$ & $<2$ & Negative \\
\hline \multirow[t]{2}{*}{12} & Storage Container & $>57000$ & 1600 & 500 & 170 & Negative \\
\hline & Tap & 50 & $<2$ & $<2$ & $<2$ & Negative \\
\hline \multirow[t]{2}{*}{13} & Storage Container & 24000 & $>1600$ & $>1600$ & $>1600$ & Negative \\
\hline & Tap & 10 & $<2$ & $<2$ & $<2$ & Negative \\
\hline \multirow[t]{2}{*}{14} & Storage Container & $<10$ & $<2$ & $<2$ & $<2$ & Negative \\
\hline & Tap & 10 & $<2$ & $<2$ & $<2$ & Negative \\
\hline \multirow[t]{2}{*}{15} & Storage Container & 6100 & 23 & 23 & 23 & Negative \\
\hline & Tap & 20 & $<2$ & $<2$ & $<2$ & Negative \\
\hline \multirow[t]{2}{*}{16} & Storage Container & $>57000$ & 80 & $<2$ & $<2$ & Negative \\
\hline & Tap & 15 & $<2$ & $<2$ & $<2$ & Negative \\
\hline \multirow[t]{2}{*}{17} & Storage Container & $>57000$ & 430 & 11 & 11 & Negative \\
\hline & Tap & 20 & $<2$ & $<2$ & $<2$ & Negative \\
\hline \multirow[t]{2}{*}{18} & Storage Container & 29000 & 30 & 7 & 6 & Negative \\
\hline & Tap & 15 & $<2$ & $<2$ & $<2$ & Negative \\
\hline \multirow[t]{2}{*}{19} & Storage Container & 19000 & 80 & 2 & 2 & Negative \\
\hline & Tap & 10 & $<2$ & $<2$ & $<2$ & Negative \\
\hline
\end{tabular}


ISSN 1555-9033

\begin{tabular}{rlccccc}
20 & Storage Container & $>57000$ & $>1600$ & $>1600$ & 50 & Negative \\
& Tap 21 & 25 & $<2$ & $<2$ & $<2$ & Negative \\
& Storage Container & 28000 & 1600 & 300 & 7 & Negative \\
& Tap 22 & 90 & $<2$ & $<2$ & $<2$ & Negative \\
& Storage Container & 24000 & 34 & 4 & $<2$ & Negative \\
& Tap & $<10$ & $<2$ & $<2$ & $<2$ & Negative \\
23 & Storage Container & $>57000$ & 900 & 29 & 29 & Negative \\
& Tap & 15 & $<2$ & $<2$ & $<2$ & Negative \\
24 & Storage Container & $>57000$ & $>1600$ & $>1600$ & $>1600$ & Negative \\
& Tap & 330 & 6 & 4 & 4 & Negative \\
25 & Storage Container & 17000 & 900 & 13 & 13 & Negative \\
& Tap & 80 & $<2$ & $<2$ & $<2$ & Negative \\
26 & Storage Container & $>57000$ & 36 & 32 & 32 & Negative \\
& Tap & $<10$ & $<2$ & $<2$ & $<2$ & Negative \\
27 & Storage Container & 5800 & 300 & 110 & 12 & Negative \\
& Tap & 15 & $<2$ & $<2$ & $<2$ & Negative \\
28 & Storage Container & $>57000$ & $<2$ & $<2$ & $<2$ & Positive \\
& Tap & 10 & $<2$ & $<2$ & $<2$ & Negative \\
\multirow{2}{*}{ Main Tank } & Supply inlet & 10 & $<2$ & $<2$ & $<2$ & Negative \\
& Cistern storage & 10 & $<2$ & $<2$ & Negative \\
\hline
\end{tabular}

\section{Chlorine results}

There was no colorimetric change in any of the field test strips for total and free chlorine concentrations at each household sampled, indicating chlorine concentrations $<0.5 \mathrm{ppm}$.

\section{DISCUSSION}

Samples from the main storage tank indicate aerobic bacteria, total coliform, fecal coliform, and E. coli levels were at or below the detection limit, indicating little to no microbiological contamination of the source water. Further, 25 of the 28 samples from the household supply taps exhibited total coliform, fecal coliform, and E. Coli below the detection limit; of those 25 samples, the aerobic bacteria concentrations were $<100 \mathrm{CFU} / \mathrm{mL}$, which is not uncommon in well water and does not necessarily indicate a public health hazard. vii Only two households (\#2 and \#24) showed elevated levels of indicator bacteria. Our data suggests that water from the tap is not contaminated when it reaches the households, and that contamination occurs during storage.

In a pre-intervention baseline sampling of traditional and modified drinking water storage containers in San Juan Sacatepequez, Guatemala, Rangel et al. reported a mean E. coli range of 324 to 2,553 MPN. viii In a stored drinking water study of peri-urban households in Lima, Peru, Oswald et al. reported a geometric mean for E. coli in principal water storage containers of 16 CFU/100mL.iii In Hyderabad, India, Eshcol et al. found a decrease in total coliform count with increased storage time (though this trend was not statistically significant), reporting a mean of $753 \mathrm{CFU} / 100 \mathrm{~mL}$ in samples collected from drinking water in storage containers less than 24 hours, and $228 \mathrm{CFU} / 100 \mathrm{~mL}$ in samples collected from drinking water stored over 24 hours. $^{\text {iv }}$ In 
Kibera, near Nairobi, Chemuliti et al. reported a mean total bacteria count of $47 / 100 \mathrm{~mL}$ in tank/standpipe water compared to $818 / 100 \mathrm{~mL}$ for in-house drinking water storage containers; these samples were not matched, as in our study. ${ }^{\mathrm{v}}$ Chemuliti also reported a mean fecal coliform count of 93/100mL for tank/standpipe water and 103/100mL for in house drinking water storage containers. $^{v}$ In Vellore, India, Brick et al. reported E. coli counts of 440 to $>3600 / \mathrm{mL}$ in the municipal water supply; after 1 to 9 days of storage at the household level, 67\% of the homes sampled showed increased contamination. ${ }^{\mathrm{vi}}$

The US Environmental Protection Agency (US EPA) recommends a total coliform (fecal coliform and E. coli) concentration level of zero, but the enforceable maximum concentration is more complicated. The US EPA requires that less than $5.0 \%$ of water samples test positive for total coliform or a maximum of one sample if less than 40 samples were taken in a month; samples that test positive for total coliform must also be tested for fecal coliform or $E$ coli. ${ }^{\text {ix }}$ The World Health Organization (WHO) recommends water intended for human consumption contain no indicator organisms, including E. coli and fecal coliform. ${ }^{x}$ More specifically, they recommend no $E$. coli or thermo-tolerant bacteria present in the water entering or in the distribution system and all water directly intended for drinking. ${ }^{x}$ By comparison to these standards, bacteria counts were above US EPA and WHO limits in most samples collected from the water storage containers of each household, for total coliform, E. coli and fecal coliform. While contaminants were present in low levels in some of the tap samples, the elevated geometric means were largely a result of the sample from Household \#2. The high contaminant concentration in the tap sample from Household \#2 may be the result of gross contamination of the tap or possible sample contamination.

Possible sources of water contamination may be related to hand hygiene and water handling. Most drinking water storage containers had a lid of some sort (from tight-fitting plastic lids, to plastic bags, plywood, and metal plates), but were not always in place at the time of our observations. Many of the storage containers were located outdoors but under an overhead covering. Domestic and farm animals lived and roamed in the household area. One sample from a drinking water storage container was positive for the detection of the presence of Salmonella. The source and species of Salmonella is not known; the storage container could have been contaminated directly or indirectly by an individual who had Salmonella gastroenteritis, or it could have an animal source. It is notable that total coliform, fecal coliform and $E$. coli were below the limit of detection in the sample that tested positive for Salmonella. This demonstrates the limitations of these indicator bacteria as predictors of this pathogen in stored drinking water.

Total and free chlorine levels in the water were $<0.5 \mathrm{ppm}$, suggesting little to no chlorine content in the water despite the community's recent effort to implement a chlorination system. Given the inadequate chlorination, it is not surprising that coliform bacteria were present in the water storage and distribution system. Providing the community guidance on the proper dosing of chlorine for their system, as well as a sufficient supply of chlorine, is an immediate priority.

Our results are consistent with other studies as we conclude that safer methods for storing drinking water at the household level are needed. i-iv,vi,xi $^{-}$System operations, monitoring, maintenance and decision making must be formalized, addressing the financial, social and behavioral factors that are critical to safe drinking water intervention success. ${ }^{\text {xii }}$ Our ultimate goal is to eliminate the need for drinking water storage at the household level by engineering an uninterrupted water supply for this community. ${ }^{\text {iv }}$ 


\section{CONCLUSIONS}

Our data demonstrate that the bacterial contamination in drinking water is substantially worse in the drinking water storage containers used at individual households than in the upstream storage and distribution system. This is consistent with the insufficient chlorination of the supply water, and may also reflect additional contamination that occurs during storage. Although many potential compromised hygiene and sanitation mechanisms exists to contribute to the burden of diarrheal illness in this rural community, the storage of drinking water is likely a major contributor to overall morbidity. Though the community had made recent efforts to chlorinate their drinking water supply, we have demonstrated here that the effort is inadequate; additional resources and training will be needed.

\section{ACKNOWLEDGMENTS}

A special thanks to University of Illinois at Chicago Engineers Without Borders student chapter members Frank Zurek, Jennifer Welch, Kate Gresh, Jason Lotter, Shawon Carlstrom, Oswaldo Garza, Amber Seiber, Carlos Mendez, and Ulrike Frangos; and Nancy Cohen from the University of Illinois at Chicago College of Engineering.

\section{REFERENCES}

${ }^{i}$ P. Jensen, J. Ensink, G. Jayasinghe, W. van der Hoek, S. Cairncross, A. Dalsgaard, “Domestic transmission routes of pathogens: the problem of in-house contamination of drinking water during storage in developing countries.” Tropical Medicine and International Health, Vol. 7 (2002): 604

iiT. Clasen and A. Bastable, "Faecal contamination of drinking water during collection and household storage: the need to extend protection to the point of use.” Journal of Water and Health, Vol. 1 (2003): 109

iii W. Oswald, A. Lescano, C. Bern, M. Calderon, L. Cabrera, R. Gilman, "Fecal contamination of drinking water with peri-urban households, Lima, Peru.” American Journal of Tropical Medicine and Hygiene, Vol. 77 (2007): 699

iv J. Eshcol, P. Mahapatra, S. Keshpagu. "Is fecal contamination of drinking water after collection associated with household water handling and hygiene practices? A study of urban slum households in Hyderabad, India.” Journal of Water and Health, Vol. 7 (2009): 145

vJ. Chemuliti, P. Gathura, M. Kyule, F. Njeruh, "Bacteriological qualities of indoor and out-door drinking water in Kibera sub-location of Nairobi, Kenya.” East African Medical Journal, Vol. 79 (2002): 271

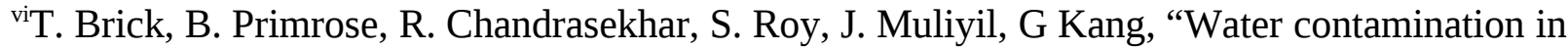
urban south India: household storage practices and their implications for water safety and enteric infections." International Journal of Hygiene and Environmental Health, Vol. 207 (2004): 473

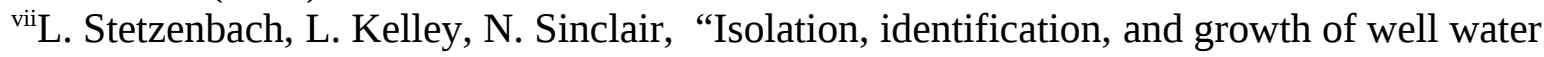
bacteria.” Ground Water, Vol. 24 (1986), 6-10.

viiiJ. Rangel, B. Lopez, M. Mejia, C. Mendoza, S. Luby, “A novel technology to improve drinking water quality: a microbiological evaluation of in-home flocculatin and chlorination in rural Guatemala.” Journal of Water and Health, Vol. 1 (2003) 15 
${ }^{\text {ix} U n i t e d ~ S t a t e s ~ E n v i r o n m e n t a l ~ P r o t e c t i o n ~ A g e n c y, ~ O f f i c e ~ o f ~ G r o u n d ~ W a t e r ~ a n d ~ D r i n k i n g ~ W a t e r, ~}$ Contaminants, June 2003, Washington, DC. Accessed on 15 March 2009 at $<$ http://www.epa.gov/safewater/contaminants/index.html\#1>.

${ }^{x}$ World Health Organization, Guidelines for drinking-water quality 2006, 3rd edition, Vol. 2, (2006) Geneva.

${ }^{x i}$ J. Wright, S. Gundry, R. Conroy, "Household drinking water in developing countries: a systematic review of microbiological contamination between source and point-of-use." Tropical Medicine and International Health, Vol. 9 (2004): 106

xiideWilde, C., Milman, A., Flores, Y., Salmeron, J. \& Ray, I. “An integrated method for evaluating community-based safe water programmes and an application in rural Mexico.” Health Policy and Planning, Vol. 23 (2008), 452-464. 